\title{
SELECTIVE INCORPORATION OF D-AMINO ACID ESTERS INTO PEPTIDES CATALYZED BY ALCALASE IN T-BUTANOL
}

Shui-Tein Chen"*, Chen-Chen $\mathrm{Tu}^{\mathrm{c}}$, and Kung-Tsung Wang ${ }^{\mathrm{ab} . *}$

a. Institute of Biological Chemistry, Academia Sinica.

b. Department of Chemistry, National Taiwan University.

c. Graduate Institute of Biochemical Sciences, National Taiwan University.

(Received in USA 16 December 1992)

Abstract: Procedures have been developed for alcalase-catalyzed selective incorporation of esters of D-amino acid into peptides in t-butanol via a selective hydrolysis of esters of DL-amino acid, followed by using the unhydrolyzed D-esters as a nucleophile in a kinetically controlled peptide bond formation.

Recently, the search for proteases that are stable in organic solvents for peptide synthesis has been the subject of extensive investigation. ${ }^{1.2}$ Here we report a two-step one-pot synthesis procedure, by which esters of D-amino acid can selectively incorporate into peptides using a kinetically controlled approach in t-butanol. The protocol of this synthesis is a sequential reaction starting with a kinetic resolution of esters of DL-amino acid and followed by a kinetically controlled approach. As shown in Scheme I, the ester of DL-amino acid was resolved in t-butanol containing $5 \%$ of water and after half of the ester of DL-amino acid was hydrolyzed, a solution of esters of N-protected L-amino acid was added to the above reaction mixture. The esters of $\mathrm{N}$-protected L-amino acid were reacted with the enzyme to form an intermediate "acyl-enzyme", and the intermediate in turn was attacked by the nucleophile, here the resolved ester of D-amino acid, to produce a peptide which contained D-amino acid residue.

Scheme I. Selective incorporation of esters of D-amino acid into peptides catalyzed by alcalase in t-butanol.
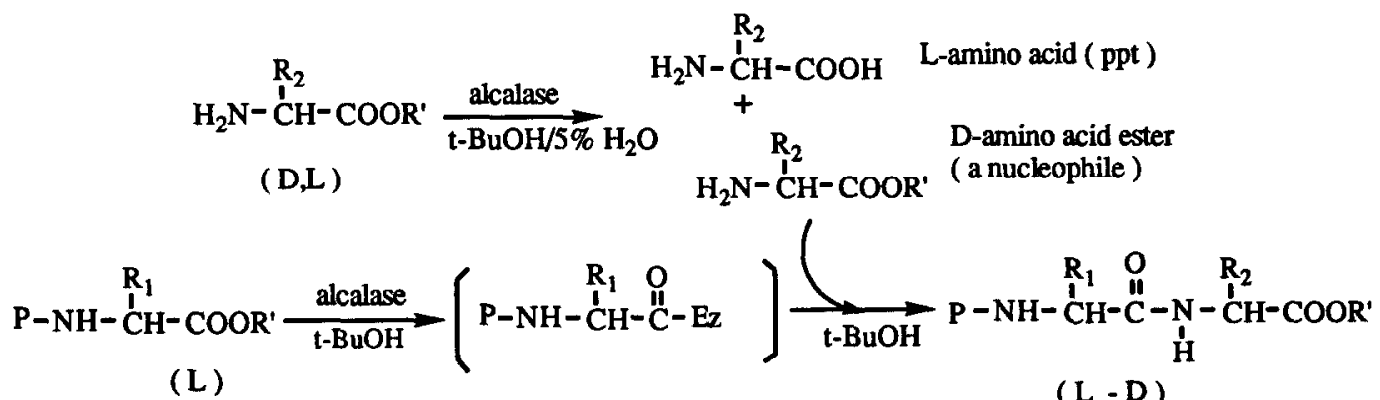

\# abbreviations: Phe, phenylalanine; Ala, alanine; Val, valine; Tyr, tyrosine; Asp, aspartic acid; Leu, leucine; Me, methyl ester, Prn $^{n}$ n-propyl ester; Bzl, benzyl ester; Moz, p-methoxylbenzyloxycarbonyl. 
The substrates were simply prepared by the established method. ${ }^{3}$ In a prelimanary reaction, when DL-PheOMe. $\mathrm{HCl}^{*}(10 \mathrm{mmol}, 2.15 \mathrm{~g})$ was incubated at $35^{\circ} \mathrm{C}$ for $1 \mathrm{~h}$ in a mixture of t-butanol $(45 \mathrm{~mL})$, water $(5 \mathrm{~mL})$, and triethylamine (1.4 mL, $10 \mathrm{mmol})$ with alcalase $(2 \mathrm{~mL})$, L-Phe $(0.76 \mathrm{~g}, 4.6 \mathrm{mmol}, 92 \%$ yield, $82 \% \mathrm{ee})$ and D-Phe-OMe $(0.96 \mathrm{~g}, 4.45 \mathrm{mmol}, 89 \%$ yield, $89 \% \mathrm{ee})$ were obtained after a simple isolation. During the course of hydrolysis, L-Phe was precipitated from the reaction solution. This may have been due to the low solubility of free amino acid in high a concentration of t-butanol. In a similar manner, DL-Ala-OPr ${ }^{n}$, DL-Val-OMe, and DL-Tyr-OMe were enantioselectively hydrolysed and isolated. The results are summarized in Table 1 . The optical purity of the amino acid was determined by using a chiral column ${ }^{4}$ and by measuring the optical rotation. Figure 1 shows a typical measurement of D-Tyr-OMe and L-Tyr. For further reaction, the above solution was evaporated to dryness for a kinetically controlled synthesis.

Table 1 Resolution of esters of DL-amino acid in t-butanol/water catalyzed by alcalase.

\begin{tabular}{lllll}
\hline Substrate & \multicolumn{3}{c}{ L-amino acid } & \multicolumn{2}{c}{ D-amino acid ester } \\
& yield & ee & yield & œe \\
\hline Ala-OPr & 91 & 100 & 89 & 93 \\
Val-OMe & 89 & 99 & 88 & 90 \\
Phe-OMe & 92 & 82 & 89 & 89 \\
Tyr-OMe & 90 & 100 & 92 & 97 \\
Leu-OMe & 89 & 95 & 87 & 91 \\
\hline
\end{tabular}

Figure 1.Measurement of enantiomeric excess of resolved L-Tyr (Fig 1-b) and DL-tyr-OMe (Fig 1-a) by hplc. The hplc consisted of an Alcott 760-hplc pump, a Soma S-3702 UV Detector and the data was collected on a Mac. LCII with a Rainin Chrompic ${ }^{\mathrm{MM}}$ sofeware. Column: CrownPak CR(t). eluent: $\mathrm{HClO}_{4} /$ water, $\mathrm{pH} 1.5$. flow rate: $1 \mathrm{~mL} / \mathrm{min}$. UV wavelength: $200 \mathrm{~nm}$.
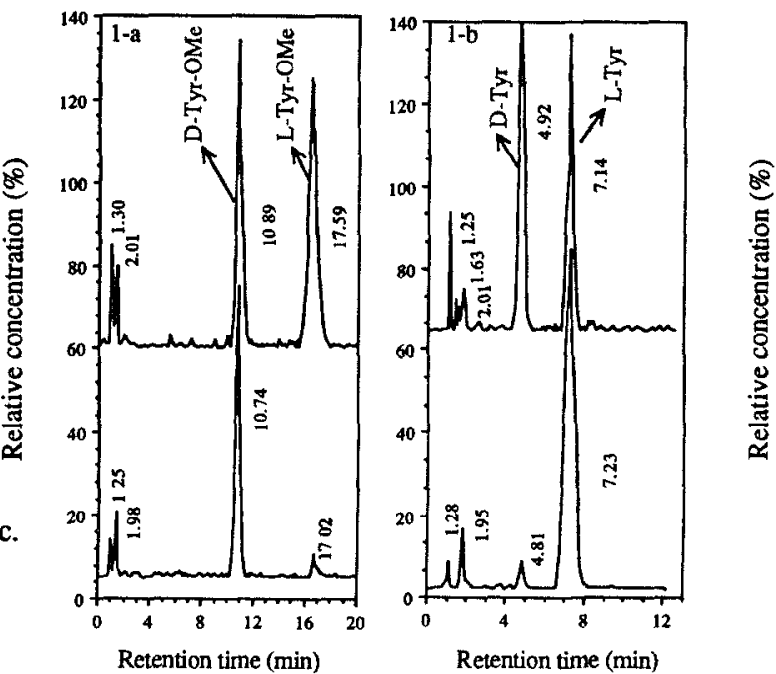

The alcalase was obtained as a brown liquid ${ }^{5}$. The enzyme did not dissolve in t-butanol, but it did disperse well in alcoholic solvents to make a transparent solution. Since water can compete with the amine nucleophile in kinetically controlled amide bond formation, the concentration of water in the reaction solution will affect the yield of the reaction. The water can be removed from the alcalase solution by repeated washing with anhydrous alcohol. ${ }^{6}$ A preliminary test, using Moz-Phe-OMe $(0.69 \mathrm{~g}, 2 \mathrm{mmol})$ in t-butanol $(15 \mathrm{~mL})$, containing alcalase $2.5 \mathrm{~L}(2 \mathrm{~mL}$, prewashed with tbutanol), and resolved D-Ala-OPr" (5 mmol, resovled from DL-Ala-OPr" $10 \mathrm{mmol}$ ), was reacted for 12 hours. Moz-Phe-D-Ala-OPT $(0.71 \mathrm{~g}, 1.62 \mathrm{mmol}, 81 \%$ yield $)$ was obtained. For following the reaction course, hplc was used to monitor the concentration decrease of Moz-Phe-OMe. Figure 2 shows the time courses of the reaction. The Moz-

Phe-D-Ala-OPr ${ }^{n}$ was increased to a concentration of $85 \%$, and a small amount of the hydrolysis byproduct Moz-Phe$\mathrm{OH}$ was observed during the reaction. This may have been due to the water molecules that associated with the enzyme 
and were put into the reaction solution. In a similar manner, Moz-Asp(Bzl)-D-Ala-OPr", Moz-Tyr-D-Ala-OPr", Moz-Phe-D-Leu-OMe, and Moz-Asp(Bzl)-Tyr-OMe were synthesized. The results are summarized in Table 2. The yield of products was between $50 \%-81 \%$. All the products conformed with the authentic samples and with ${ }^{1} \mathrm{H}-\mathrm{NMR}$ and FAB Mass spectra.

Figure 2. Time courses for alcalase catalyzed MozPhe-D-Ala-OPr formation in t-butanol. The hplc consisted of an Alcott 760-hplc pump, a Soma S-3702 UV Detector and the data was collected on a Mac. LCII with a Rainin Chrompic ${ }^{\mathrm{mM}}$ sofeware.

Column: RP-18, $4.6 \times 150 \mathrm{~mm}$. eluent: $40 \% \mathrm{CH}_{3} \mathrm{CN}$ in $0.1 \%$ TFA. flow rate: $1 \mathrm{~mL} / \mathrm{min}$. UV wavelength: $254 \mathrm{~nm}$.

Table 2. Kinetically controlled peptide bond formation

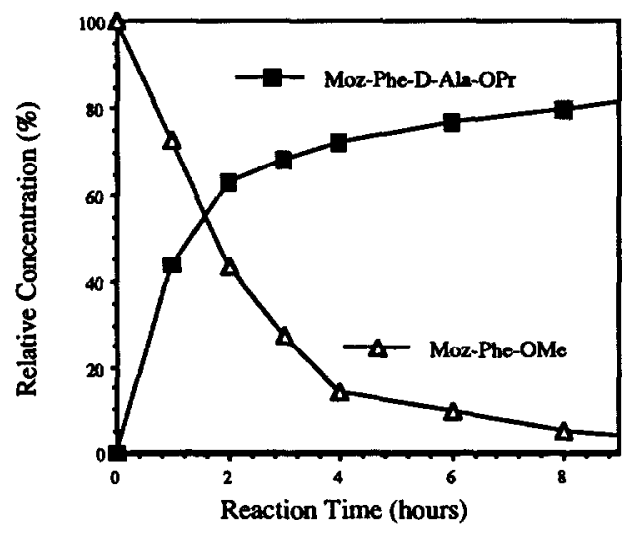
catalyzed by alcalase.

\begin{tabular}{|c|c|c|c|c|c|c|}
\hline Acyl donor & nucleophile & product & $\begin{array}{l}\text { yield } \\
\% \\
\end{array}$ & {$[\alpha]_{D}$} & ${ }^{\circ} \mathrm{Cp}:$ & $\begin{array}{l}\text { FAB mass } \\
\mathrm{MW}^{+1}\end{array}$ \\
\hline Moz-Tyr-OMe & Ala-OPrn & Moz-Tyr-D-Ala-OPr" $(1)$ & 48 & +4.45 & $125-126$ & 481 \\
\hline Moz-Asp(Bzl)-Bzl & Ala-OPr ${ }^{n}$ & Moz-Asp(Bzl)-D-Ala-OPrn (2) & 65 & +1.69 & $92-93$ & 523.2 \\
\hline Moz-Asp(Bzl)-Bzl & Tyr-OMe & Moz-Asp(Bzl)-D-Tyr-OMe(3) & 63 & -0.69 & $111-112$ & 587.2 \\
\hline Moz-Phe-OMe & Leu-OMe & Moz-Phe-D-Leu-OMe(4) & 59 & +7.50 & $134-135$ & 457.3 \\
\hline Moz-Phe-OMe & Ala-OPrn & Moz-Phe-D-Ala-OPr ${ }^{n}(\mathbf{5})$ & 81 & -0.84 & $120-121$ & 465 \\
\hline
\end{tabular}

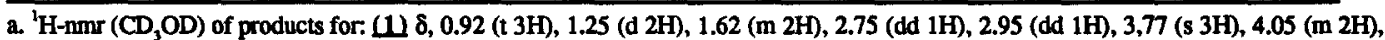
4.32 (q 2H), 4.94 (s 2H), 6.68 (d 2H), $6.85(\mathrm{~d} 2 \mathrm{H}), 7.01$ (d 2H), $7.18(\mathrm{~d} 2 \mathrm{H}) ;(2)$ ) 8.9 .91 (t 3H), 1.34 (d 3H), 1.57-1.68 (m 2H), 2.70 (dd 1H), 2.88 (dd $1 \mathrm{H}), 3.76(\mathrm{~s}, 3 \mathrm{H}), 3.99-4.08(\mathrm{~m} \mathrm{2H}), 4.35$ (q 1H), $4.58(\mathrm{~g}, 1 \mathrm{H}), 5.00(\mathrm{~s}, 2 \mathrm{H}), 5.08(\mathrm{~s} 2 \mathrm{H}), 6.86(\mathrm{~d} \mathrm{2H}), 7.26-7.33$ (m 7H); (3) $8,2.61$ (dd 1H), 2.75 (dd lH), 2.86 (dd 1H), 2.99 (dd 1H), 3.75 (s 3H), 4.56 (q 2H), 4.83 (s 3H), 4.98 (s 2H), 5.05 (s 2H), 6.67 (d

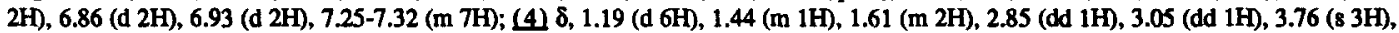
4.30 (q 1H), 4.35 (q 1H), 4.83 (s 3H), 4.93 (s 2H), $6.85(\mathrm{~d} \mathrm{2H}), 7.16-7.27$ (m 7H); (5) $8,0.92$ (t 3H), 1.23 (d 3H), 1.60-1.67 (m 2H), 2.85 (dd 1H), 3.05 (dd 1H), 3.77 (s 3H), 4.02-4.04 (m 2H), 4.28 (q 1H), 4.37 (q 1H), 4.94 (s 2H), 6.85 (d 2H), 7.16-7.27 (m 7H).

The alcalase with enantioselectivity has been used for resolution of DL-amino acid in aqueous solution ${ }^{7}$ and of $\mathrm{N}$-protecied DL-amino acid in t-butanol containing $5 \%$ buffer. $^{8}$ The enantioselectivity of alcalase catalyzed resolution of $\mathrm{N}$-free anino acid derivatives was high also. In a representative preparative scale reaction, when DL-Tyr-OMe. $\mathrm{HCl}(46 \mathrm{~g}, 0.20 \mathrm{~mol})$, triethylamine $(28 \mathrm{~mL})$, and alcalase $2.5 \mathrm{~L}(10 \mathrm{~mL})$ were incubated in a mixture of t-butanol $(200 \mathrm{~mL})$ and water $(10 \mathrm{~mL}), \mathrm{L}-\mathrm{Tyr}(16.47 \mathrm{~g}, 90 \%$ yield, $98 \%$ ee) and D-Tyr-OMe.HCl $(21.25 \mathrm{~g}, 92 \%$ yield, $97 \% \mathrm{ce})$ was obtained.

In conclusion, this procedure provided a new method for both amino acid resolution and selective peptide bond formation. The resolution of $\mathrm{N}$-terminal-free amino acid derivatives in high concentration organic solvent has not been report before. Most of the amino acid is insoluble in organic solvent. The precipitated amino acid can easily be separated by centrifugation. This is better than traditional resolution in aqueous solution. Using an inexpensive 
industrial enzyme as a catalyst makes the process potentially useful for large scale synthesis. The Moz-Asp(Bzl)-DAla-Pr" is a precusor of a reported antificial sweetner ${ }^{9}$. In conclusion, the alcalase-catalyzed peptide bond formation is regioselective for the $\alpha$-carboxyl of Asp residues, and enantioselective for the L-amino acid substrates at the enzyme's p-1 sub-site. This new enzymatic process has several advantages: 1) the high turnover rate and low cost of the enzyme make enzyme immobilization unnecessary; 2) the enzyme is stable in alcoholic solvent, thus allowing operation at high substrate concentration; and 3) product isolation is simple.

\section{Acknowledgment.}

Support for this research provided by the National Science Council, Taiwan, (NSC 81-0208-N-001-70 \& NSC820115-C001-01-078M) is gratefully acknowledged.

\section{Reference.}

1. a) Wong, C.H., Wang, K.T., Experientia, 1991, 47, 1123-1129.

b) Schellenberger, V.. Jakubke, H.D., Angew Chem, Int. Ed. Engl. 1991, 30, 1437-1449.

c) Klibanov, A.M., Chemtech. 1986, 16. 354-359.

d) Kuhl, P., Halling, P.J., Jakubke, H.D., Tetrahedron Lett. 1990, 31, 5213-5216.

e) West, J.B., Wong, C.H., Chem. Commun. 1986, 417-418.

f) Margolin, A.L., Tai, D.F., Klibanov, A.M., J. Am. Chem. Soc. 1987, 109, 7885-887.

g) Stahl, M., Mansson, M.O., Mosbach, K., Biotech. Letters, 1990 , 12(3), $161-166$.

h) Barbas, C. F(III)., Wong, C. H., Chem. Commun. 1987, 532-534.

i) Kise, H., Bioorg. Chem. 1990, 18, 107-115.

2. a) Chen, S.T., Hsiao, S.C., Wang, K.T., Bioorg. \& Med. Chem. Letters. 1991 , 1(9), 445.

b) Chen, S.T., Chen, S.Y., Wang, K.T., J. Org. Chem. 1992 (inpress).

3. Bodanszky, M., in "Principle of Peptide Synthesis", Springer-Verlag, Berlin, 1984.

4. The CrownPak CR(+) chiral column was obtained from Diacel company, USA. The RP-18 column was packed in this lab.

5. Alcalase was purchased from NOVO industrial (Denmark) as a brown liquid with a specific activity of 2.5 AU.mL ${ }^{-1}$ (According to NOVO, one Anson-unit (AU) is the amount of enzyme which, under standard conditions, digests haemoglobin at an initial rate liberating per min an amount of TCA-soluble product which gives the same color of phenol reagents as 1 mequiv of tyrosine. Thus $1 \mathrm{AU}=1000 \mathrm{U}, 1 \mathrm{U}=1 \mathrm{mmol}$ of L-Tyr-OMe hydrolyzed per min). It was used without further purification.

6. A typical procedure for removing water from the alcalase solution was as follows: the enzyme solution was suspended in an anhydrous t-butanol by agitation, the resulting mixture was centrifuged to separate the enzyme from the solvent, and the t-butanol was removed by decantation. The procedure was repeated several times, and the enzyme was then transferred to a reaction flask for peptide synthesis.

7. a) Chen, S.T., Wang, K.T., Wong, C. H., Chem. Commu. 1986, 1514-1516.

b) Ricks, E.E., Estrada-Valdes, M.C., McLean, T.L., Iacobucci, G.A., Biotech. Prog. 1992, 8, 197-203.

8. Chen, S.T., Chen, S.Y., Hsiao, S.C., Wang, K.T., Biotech. Letters, 1991, 13(11), 773-778.

9. Takemoto,T., Hijiya, T., Yukawa, T. , Peptide Chemistry 1986, T. Miyazawa. Ed. Protein. Research Foundation. Osaka (1987) 